\title{
日本中部の気候区界について
}

$$
\text { 鈴 木 秀 夫* }
$$

\section{Ueber die Klimagrenze Zentraljapans}

Von

\section{Hideo SuzUKI}

In vorliegender Arbeit ist die Struktur der Klimagrenze Zentraljapans offenbar gemacht worden. Die Ränder der Niederschläge wurden hierbei als Merkmal gewählt. Es wurden 24 Verteilungskarten dieser Ränder von der ersten Hälfte Januars bis zur letzten Hälfte Dezembers aus 365 täglichen Niederschlagsverteilungskarten (Abb. 1 u. 2) des Jahres 1955 gebildet. Abb. 3 u. 4 sind deren zwei Beispiele. Die Zahlen dieser Linien in einem Quadrat mit der Fläche von $1.5 \times 1.5 \mathrm{~km}^{2}$ wurden auf den Abb. 5 u. 6 erwiesen. Die Zonen mit Zahlen mehr als 2 auf diesen Karten zeigen die Uebergangszonen zwischen der Klimate und die Kammlinien dieser Zonen sind die Witterungsscheiden einzelner Halbmonate. Abb. 7 stellt den jährlichen Gesamtüberblick dieser Witterungsscheiden dar. In gleicher Weise sind die Uebergangszonen und die Kammlinien festgestellt worden. (Abb. 8)

Die ungebrochenen Linien in der Abb. 3 u. 4 zeigen, dass es den Niederschlag nordseits bzw. westseits dieser Linien gibt. Die gebrochenen Linien sind die Ränder der Süd- bzw. Ostniederschläge. Die Linien in der Abb. 5, 6, 7 u. 8 folgen dementsprechend.

Das Bild einzelner Karten ändert sich sehr je nach dem Jahresverlauf der Witterung. Aber aus dem Vergleich der jährlichen Karten (Abb. 8) mit denen der monatlichen Karten (Abb. 5, 6 u. a.) kann man schliessen, dass der Hauptunterschied japanischer Klimate zwischen Hinter- nnd Vorderjapan liegt, und dieser Unterschied hauptsächlich nur in Winter, wo die dünne Kaltluft aus Sibirien herkommt, existieren kann. Im Sommer wird die Einheit der Witterung kleiner wegen der Erhitzung und der dicken Warmluft aus dem Stillen Ozean und es ergibt keinen wesentlichen Unterschied zwischen Hinter- und Vorderjapan. (Abb. 2, 4 u. 6)

Es ist auch festgestellt worden, bis zum welchen Grade der Unterschied zwischen den zwei hauptjapanischen Klimaten besteht. Die grösste Zahl 12 in der Abb. 8 in der Ecke links beweist, dass es nur während eines Halbjahres diesen Unterschied gibt, wenn halbmonatlich, wie hier, gesehen wird.

Die Feststellung der Klimaprovinzen ist durch oben gewonnenen Erkenntnisse noch unmöglich, da die Kammlinien, d. h. Klimagrenzen, nebeneirander laufen. Dafür sind noch weitere Studien über Unterprovinzen durch die anderen Merkmalen erforderlich.

Aufnahme zeigt den Rand des Niederschlags Wetterlage.

* 東京大学地理学郄室 地学雑誌 Vol. 66, No. 2 (704), 1957 


\section{I. 緒 言}

気候区界の意義は，気候要素の平均値を报つていた従来の気候学沈䦽いては，あいまいにされていた。 そこで毎日の天気現象の集合として気候をとらえた場合に，ある気候と他の気候との境界は実際どうなつ ているかということを降水量の有無を示標として調べた。その結果，気候区界の構造について一部の結論 を得たのでこつに報告する。

\section{II. 資料および方法}

日本中部を対象にしたが，このスケールの天候を最も良く表現する一つの要素は，区内観測所の降水量 であると考觉る。

24 県，約 1,000 カ所の傎を佑つて，150 万分の 1 の日雨量分布図(第 1 図，第 2 図) 365 枚を 1955 年につ いて作成してみると，全域浲水のある場合 60 回，全域浲水のない場合 19 回，部分的に 降水のある場 合が 286 回西るこぞ知られ，降水の有無が基本的な差異であり，したがつて，分布図の中で降水域端が， 最初に取り扱われるべきであることが判る。微量の記録には，それが露や霜であるか否か示されていない 場合が多かつたので，便宜的に $0.5 \mathrm{~mm}$ の線を降水域端とした。現実との違いは，距離的に重大なもの ではないと思われる。

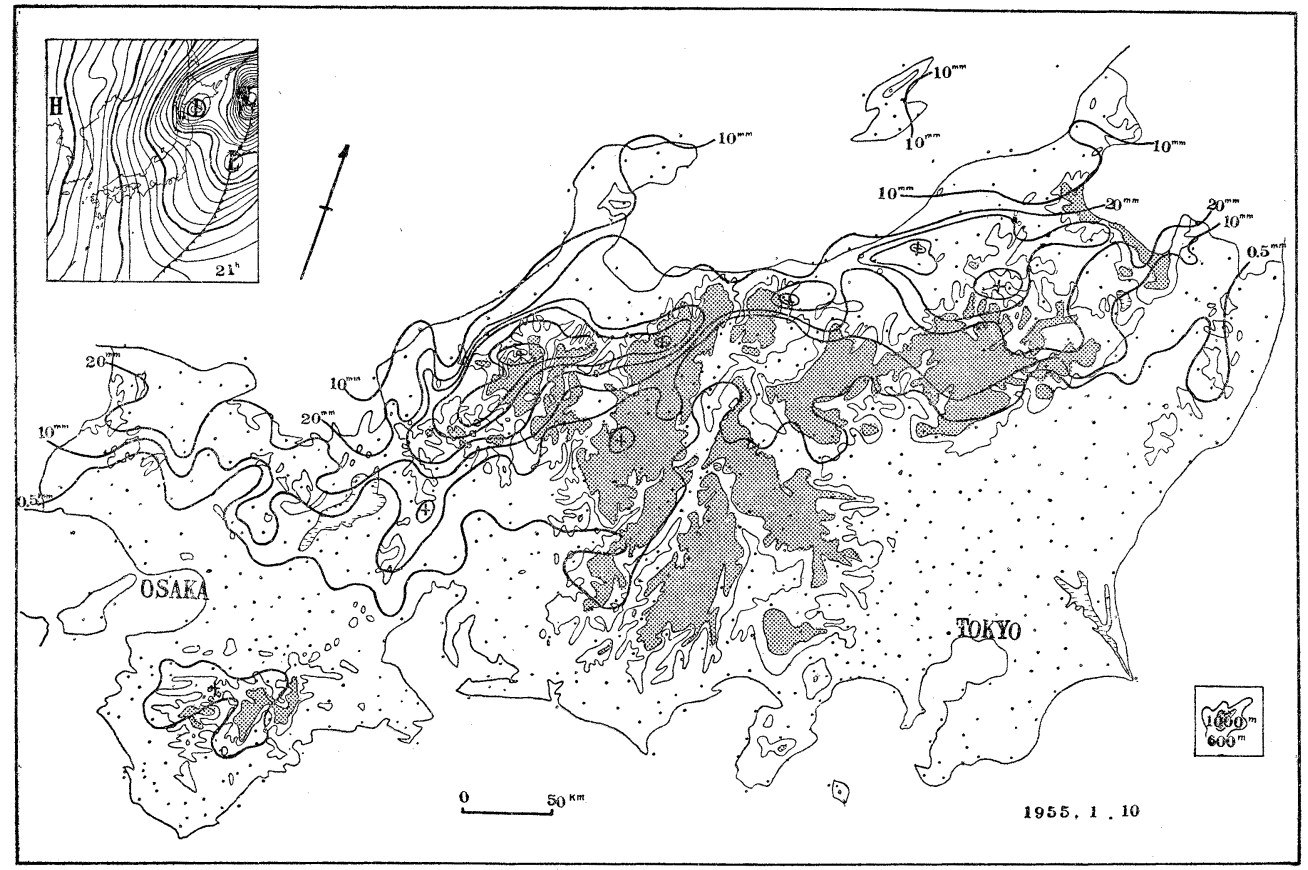

第 1 図 日雨量分布図 (冬型の典型) 図中の点は観測地点

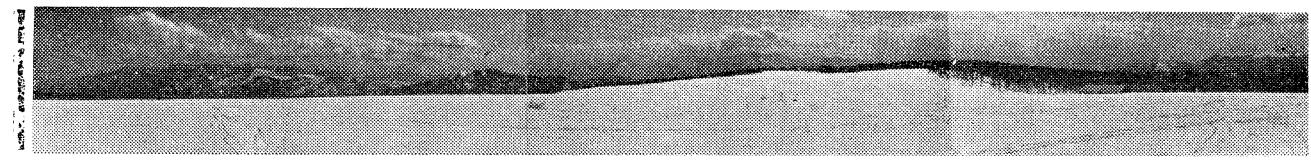

季節風による降水域端

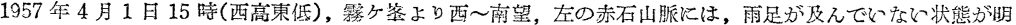
瞭にみられる（第 1 図參照)。中央は木會山脈，右は飛弾山脈（右赫は美っ原） 
天気の境，すなわち降水域の端のもつとも頻繁に現われる所を求めるために，半月ごとに， $0.5 \mathrm{~mm} の$ 線を1枚の図に重社合せた降水域端分布図(第3 図, 第 4 図) 24 枚を作り, 更に $15 \mathrm{~km}$ のメッシュをかけ て，その中を通過する本数を数え，降水域端頻度㘡を（第 5 目，第 6 図）24枚を作つた。

降水量観測の日界 9 時にまたがる降水は 2 日に分かれて表現されているから，頻度 3 までをとれば，そ の地域が漸移帯，その軸をもつて天候界と見ることができる。

この天候界と漸移帯は季節によつて著るしくその位置・形態を異にしているが，24枚上の天候界を更に 重社合せ (第 7 図)，同じネッシュで頻度図(第 8 図)を作つた。仮瀕度 5 以上の地域をとると，第 7 図と 直観的に良く相似する。したがつてこれを漸移带，その軸をもつて気候区界とすることが，もつとも妥当 であると云える。

以下, 各半月毎の図について，6時間毎の地上天気戌を参照して簡単に説明し，最後に 1 年の総括をす ることによつて，気候区界の意義について述べる。

な称，降水域端分布図(第3図，第 4 図)のなかで，実線は降水が大局的に見て以西・以北にある場合， 破線は以東・以南にある場合を示している。第 5 図以下第 8 図までそれに彷つている。

\section{III. 牛月别 天候 推移}

1 月上牛期 全域 1 , 部分 14 , 觜無 0

大陸の高気压に抏〉われ，ほとんど典型的な冬型気圧配置に終始した。降水は大部分，日本海側であつ たが，気王傾度が大きくなると，降水域は背稜山脈を越して，阿武隈・木斯・紀伊山脈にまで達した。第 1 図がそのもつとも明瞭に見られた場合であるが，半月を通じた降水域端分布図・頻度困（第 3 図，第 5 図にも同じことがはつきり現われている。すなおち, この期間は, 紀伊山脈の北側も裏日本と云うべき ことになる。

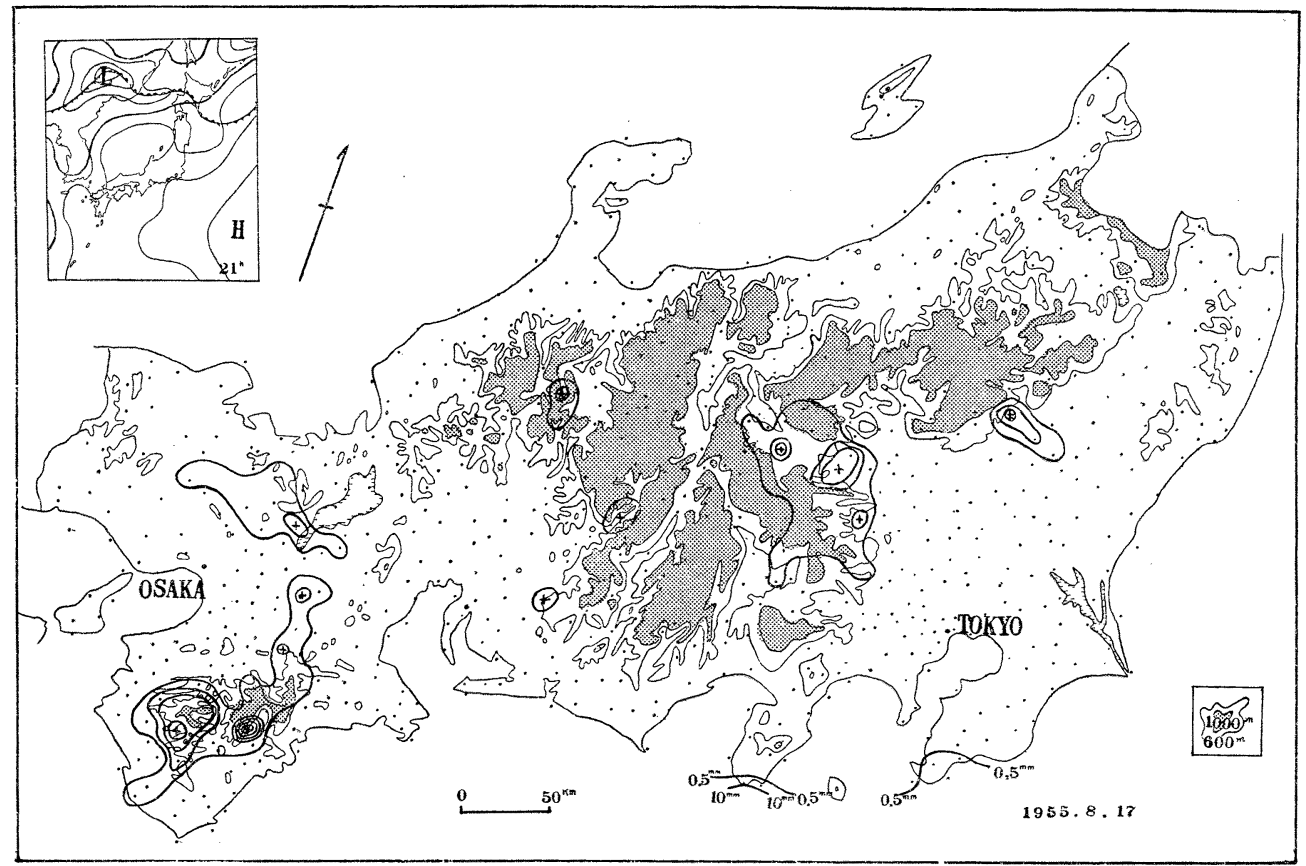

第 2 図日雨量分布図（是型の典型）図中の点は観測地点 


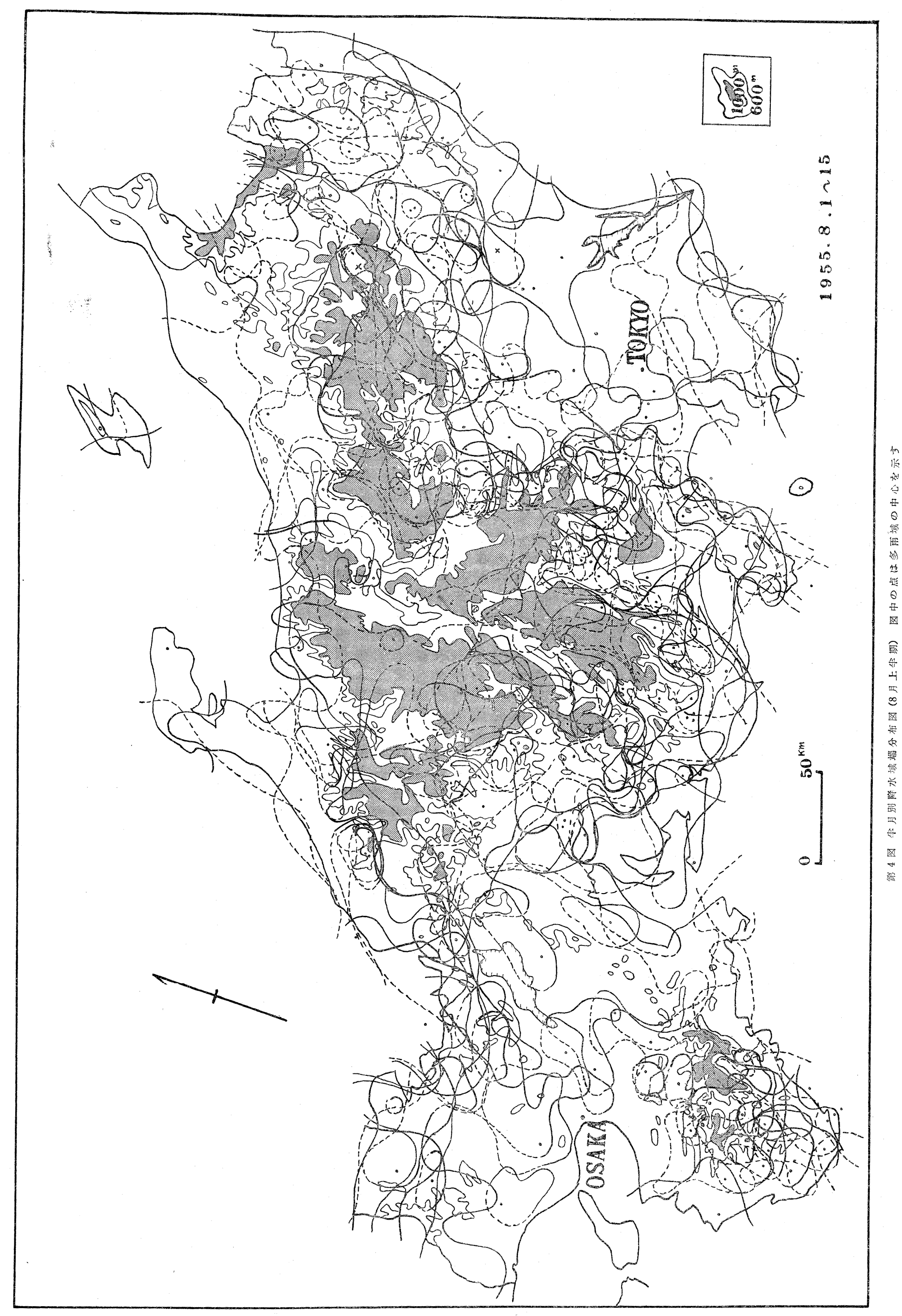


この分布は，移動性高気压・二ッ王低気圧によつてそれぞれ1回，大きくくずされた。

1 月下半期 全域 2 , 部分 14 , 皆無 0

上半期とくらべてパターンに大きな差はないが，線の集中が少くなつたこと，降水域が木賏山脈から赤 不山脈にも不んだことが注目される。たざしその 4 回のうち 2 回は前線の通過，残りの 2 回は低気圧によ るるので西るから，やはり季節風炕よる降水は木賏山脈までと云えよう。

2 月上牛期 全域 1 , 部分 14 , 皆無 0

典形的な冬形気王配置は比較的少なかつたが，降水の分布はな和日本海侧に多かつた。これが乱された のが 5 回，したがつて天気界は変動が大きく，吹越しが，阿武隈山脈・濃尾平野・紀伊山脈に至ることは 少なかつた。

2 月下半期 全域 3 , 部分 10 , 皆無 0

もはや，西高東低的気压配置は $3 \sim 4$ 回にすぎず，移動性高気圧・二ッ王＼cjkstart旋風・南高北低・東高西低

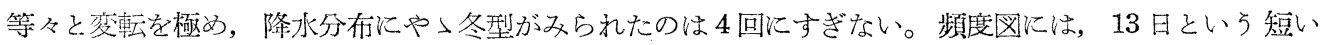

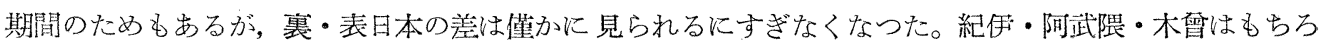
几，上越国境汇も天候界は消党た。

3 月上半期 全域 3 , 部分 11 , 㫮無 1

南岸ぞいに前線が停滞して，大平洋岸にも雨を降らせることが多く，西高東低型が狭い範四ではあつた が，な括しばしばできた。降水分布は，したがつて両者の組合せで不規則なるのが多かつたが，なお日本 海側飞多かつた。頻度図にも冬の括もかげが残つている。背稜山脈以南にも，実線・破線が散らばり，隆 水域の中心が現われて来た。紀伊山脈汇降水をもたらすような強い季節風が 2 回も吹いたことは注目に值 する。

\section{3 月下乎期 全域 7 , 部分 8 , 㫮無 1}

南岸に前線が停滞し，梅雨型の気圧配置が長く続き，冬型の降水分布は全く消隇した。部分降雨が少な いので天候界は顕著でないが，全域降水では雨量の急変部が中央山地にそつて走り，東西の差が 生じてい るのが見られる。この種の天候界は別の示標を使わぬと表現できない。たざし経続時間は短い。

4 月上午期 全域 1 , 部分 11 , 㫮無 3

移動性高気圧の影響を受けることが多く，広域に雨を見ない日が多かつた。しばしば低気圧通過後，西 高東低となつて，日本海側のみならず，紀伊にまで降水をもたらせた。頻度図にもや〉冬型が見られる。 前期に続いて，中部山地が東西の雨量の分布の差を生ぜしめているが，頻度図には，はつきりと表現され ていない。

\section{4 月下半期 全域 4 , 部分 9 , 皆無 2}

大陸の高気圧や移動性高気圧にお〉われることが相当にあり，前線が主として南方にあつた。西高型は な扮出つたが，もはや表日本の降水が圧倒的である。その雨域端である破線は，冬季の笑線と違つて毎回 の変動が大きく, 頻度図には現われにくい。中部山地による東西の差は6〜7回も認められたが，一つに は雨の有無の差ではなく量の差として現われていること，一つには地形との関連が密でないことによって 頻度図以は良く表現されていない。

5 月上华期 全域 3 , 部分 12 , 㫮無 0

部分的降水のうちには，かなり小範囲な場合が多い。分布は本数が少くて，はつきりしたことを示して いないが，和泉山脈付近にや入候界がみられる。中部山地を南北走る天候界は $3 \sim 4$ 回あつたが表現 されていない。

5 月下半期 全域 5 , 部分 9 , 皆無 2

気圧の谷が不規則的に裂来し，降水分布は今迄見られなかつた複雑な形になつた。表日本・毫日本の差 


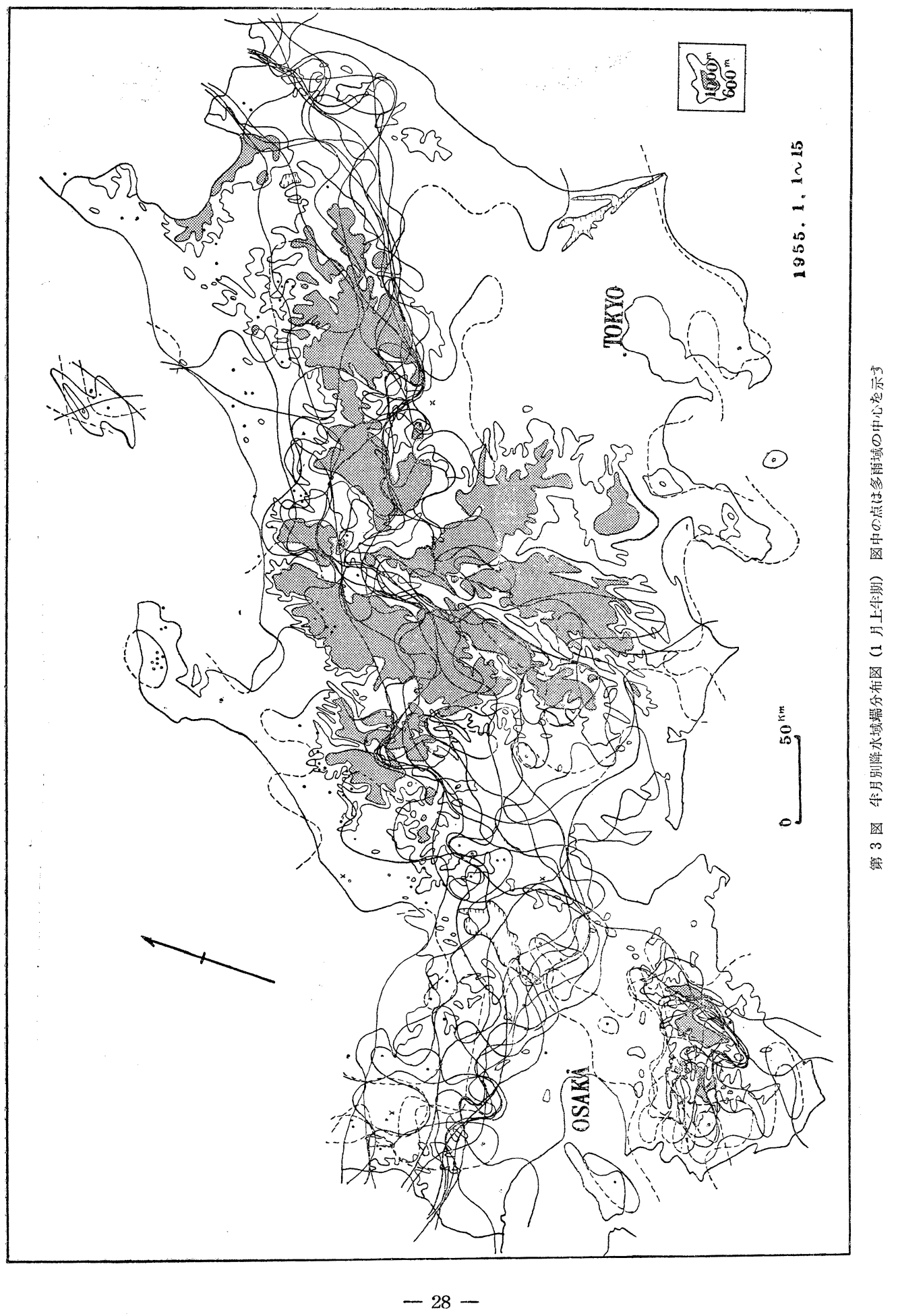


は雨の有無に関しては全然ないと見てよい。中央山地による東西の違いは 4 回ほどあるが，場所がかなり 違うのでこれも頻度図には全然現われていない。福島県の中通りに南北に近い境界が見られる。

6 月上牛期 全域 2 , 部分 13 , 皆無 0

梅雨前線が南方留まつて, から梅雨的であり, ごく局地的な雨か, あるい瑐線が接近して 経度線方 向住等雨量線が走り，春に見られた東西の差はほとんど見られなくなつた。紀伊・上越・系魚川付近に天 候界があるようである。

6 月下半期 全域 2 , 部分 13 , 皆無 0

本格的な梅雨となり，等雨量線は緯度方向に走る。前線が日本海岸に移るとその降水分布は冬型降雨と 非常に似てくる。分布図は複杂倠を極めて来た。

7 月上牛期 全域 4 , 部分 11 , 皆無 0

梅雨が北上してから東高西低が続き，紀伊南東部々関東北〜西部に降雨が続いた。これは頻度困にもは つきりと多雨带として現われている。熱的な原因が多くなつて部分的降水は小範国になつた。雨量の多い 時には，再び中央山地に東西の差が現われている。

7 月下半期 全域 2 , 部分 12 , 皆無 2

台風が去つたあと, 完全な夏型気圧配置となり, 雨の分布には熱的要素が強くなつた。局地的なものが 多く, 特に関東山縁に著るしい。したがって降水域としては, 裏・表, 東・西日本とい5大きなオーダー ではなく，一段下のオーダーで現われている。

8 月上车期 全域 0 , 部分 15 , 皆無 0

日本海に高気压があつて，典型的な夏型は少なかつたが，雨はほとんどすべて熱雷または熱界雷であつ た。第 4 図を見ると, 関東平野北一西端，紀伊山脤，甲府盆地，濃尾平野東端，金沢付近飞降水が多いこ とがわかり，第6図を見ると，寒線と破線が平行してその間に雷雨地帯があることを示している。

8 月下半期 全域 3 , 部分 12 , 皆無 1

夏型の気圧配置が復活したが，日本海にも高気圧が時々出来た。分布図はや子簡単になつて来たのは熱 的要素が減つて来たものと見られる。

9 月上午期 全域 1 , 部分 14 , 皆無 0

オホーック海から日本海にかけて高気圧がありその南端になつた。3日には小規模な西高東低となつて

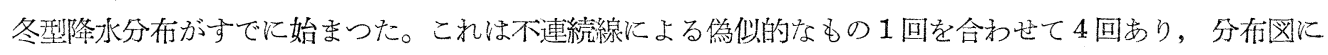
は冬型の走りが見られる。頻度図によれば, 西日本ではかなり顕著である。

9 月下半期 全域 4 , 部分 9 , 皆無 2

移動性高気圧と気圧の谷が周期的に通つた。上半期に見られた冬型の特徵は失われ，3〜 月刍の頃に似て 東西の差が出て来た。

10 月上半期 全域 2 , 部分 12 , 皆無 1

北高と西高が交代し，広範な雨が繶いた。そのため分布図は粗であるが，西日本では冬型の確立したこ とを示している。

10 月下半期 全域 6 , 部分 10 , 皆無 0

移動性高気圧と気圧の谷が 周期的に東進した。冬的降水恃 6 回に及び，分布図では冬型が支配的にな り, 東日本にも達した。

11 月上半期 全域 0 , 部分 14 , 眥無 1

大陸の高気圧，ないしはその前方の带状高気圧に 全期間芰配された，したがつて部分的降水中 12 回は 冬型である。分布図も完全な冬型であるが，気圧傾度がまだ弱いので最頻度線( 天候界)が 北答つている こと，そして能登にもできていることが目につく。木霄・紀伊山脈にも降水が巫ぶことがあるが，頻度国 にはまだ現われていない。 


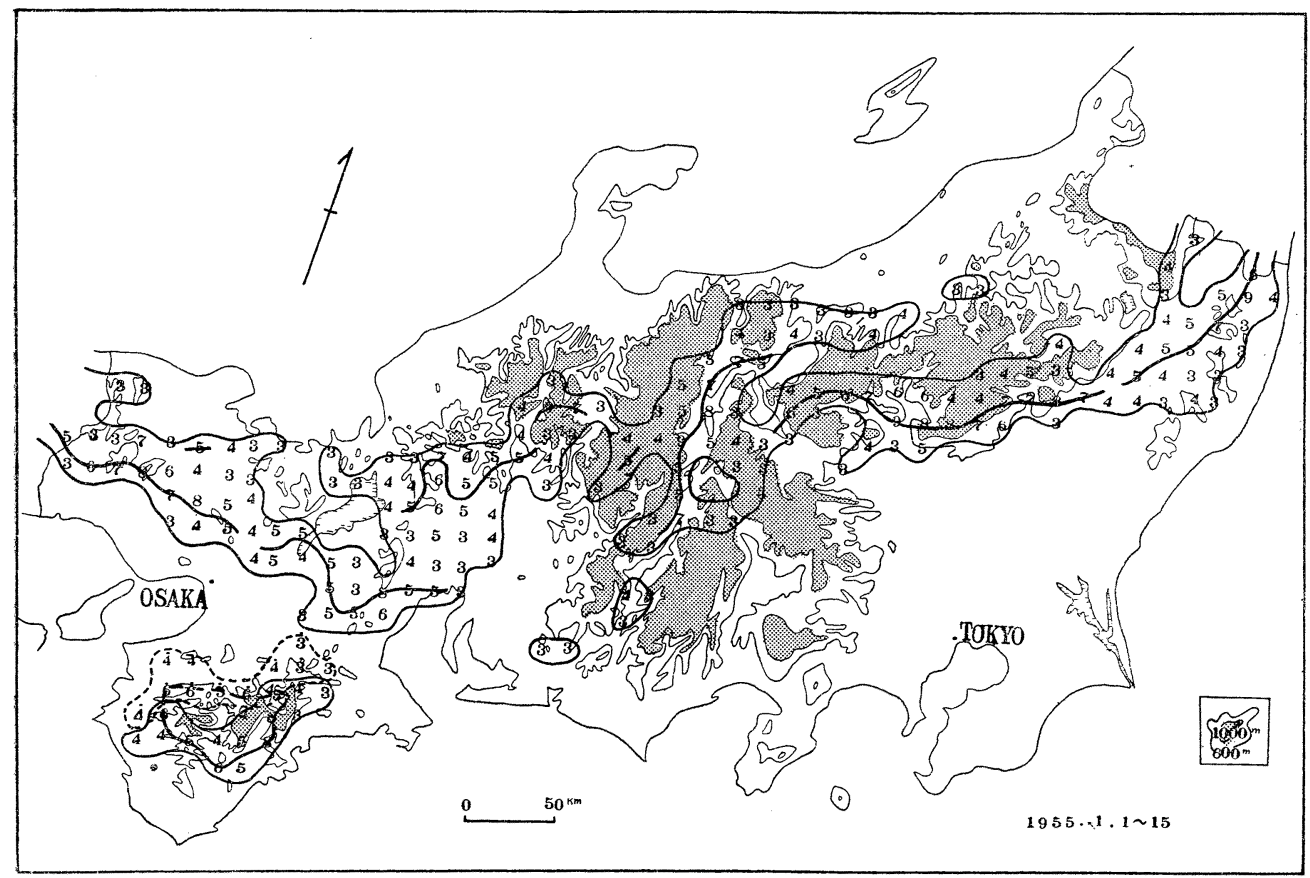

第 5 図 牛月别降水域鲕頻度図（1 月上红期）（軸線天候界）は 5 以上の部分のみを示した

11 月下半期 全域 3 , 部分 12 , 皆無 0

気圧の谷が周期的に通過して，地形との関倸が明らかでなり・降水分布が多く，分布図には上半期と比べ て再び破線が大つて冬以外の要素の存在を示している。最頻度線の位置は上半期と同じであるがや〉不明 瞭になつた。

12 月上午期 全域 0 , 部分 12 , 皆無 3

西高東低の気圧配置の発達は著るしくなかつたが，分布図・頻度図に見光る冬型は前々期程度に復旧し ている。とくに西日本では天候界は南下している。

12 月下本期 全域 1 , 部分 15 , 皆無 0

気圧の谷が 3 回通つて表日本にも降水があつたが，回復後の西高東低は傾度が大であり，分布の型はや >乱れているが，裏日本の降水量は多く，冬の盛りを示している。最多頻度線は 1 月上半期(第 5 図)には 友ばないが，1月下半期程度の南下を示している。

\section{IV, 1 年間の総括一一気候区界の意義}

以上 1 年閒を概観すると，天候界のもつとも顕著なるものは，冬型の降水に扝汿る表日本・裏日本の差 であることがわかる。これは 1 月の上半期沈つとも顕著になり， 3 月の上半期なで続いた後，消隇し， 再び 9 月の上半期に一時現われ，10 月の後半頃から本格的になつて 12 月下半期に问い，次第に 顕著にな つていく。

3 月下半期から 5 月上半期にかけては, 重・表日本の差よりも, 中部山地を界とする東西の差が現われ る。これは頻繁な高低気圧の通過が東西方向の風を起すためと思われるが，この状態は経続時聞が長くな

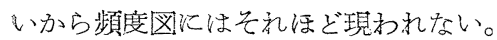

5 月下半期から 6 月にかけて, 東西の差が消光, 再び裏・表の差が現われるのは梅雨のためであり, 梅 


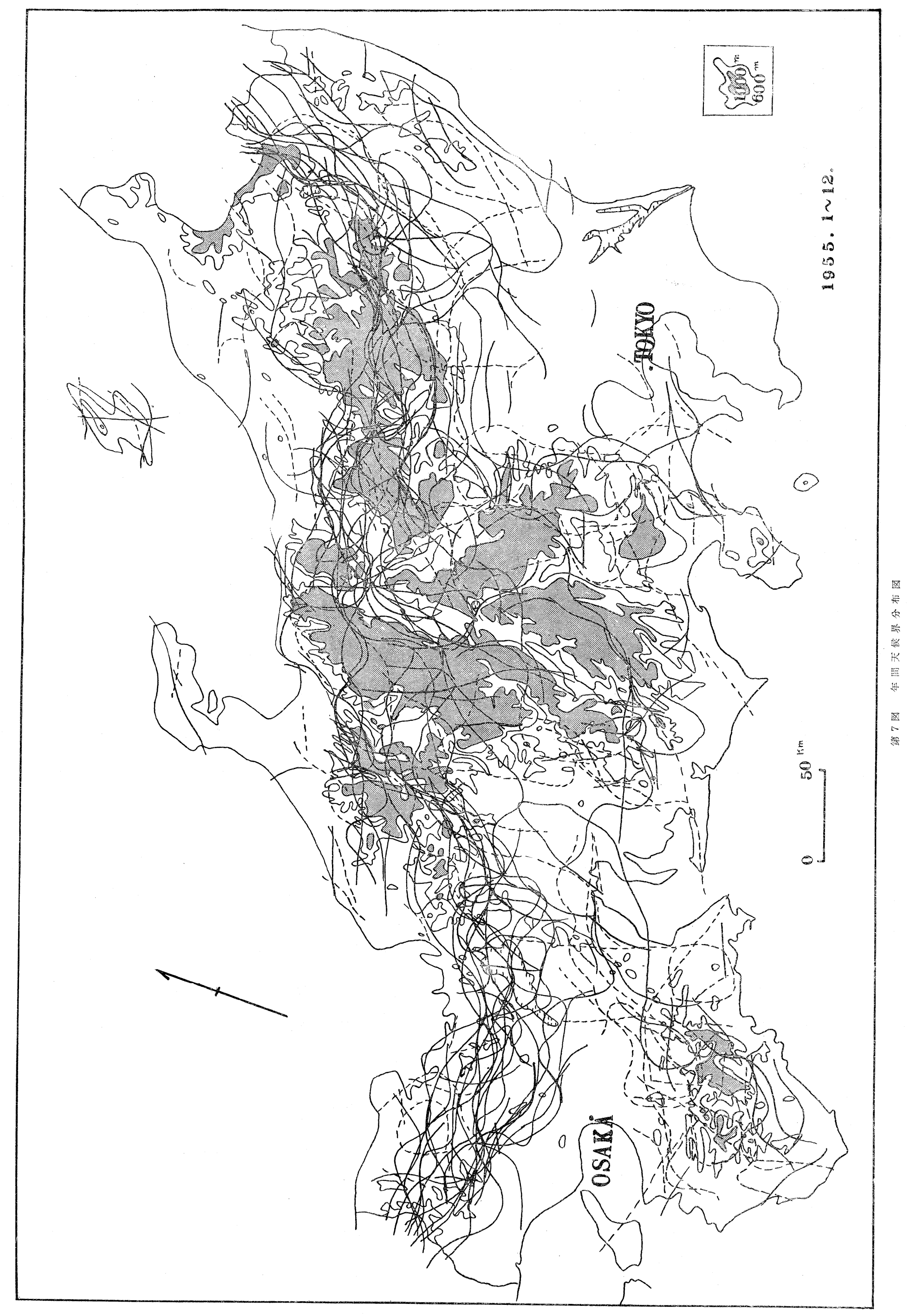




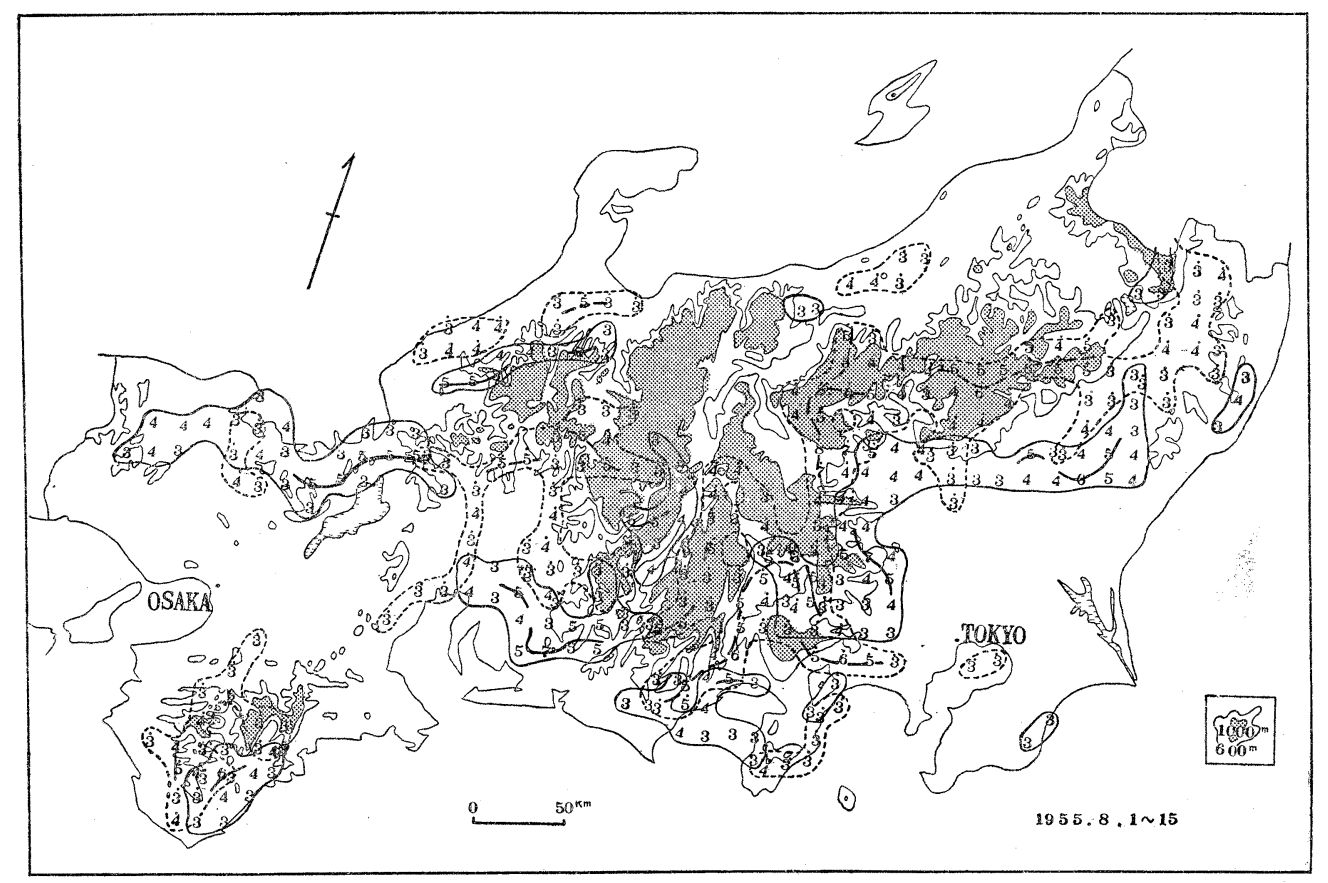

第 6 図 本月別降水域端頻度図 軸線（天续界）は 5 以上の部分のみを示した

雨が明けて夏型の気圧配置になると，兩方とも見られなくなつてしまう。そして 8 月下半期まで，局地的 な雨による細かい模様が描かれるが，夏季の空気の運動単位が細かくなつていることを示している。

9 月上半期は梅雨に似た天候で一時南北の差が出てくるが，9月下半期から 10 月上半期には再び中奂山 地を界として東西汇差が現われ，その後は冬型となつて行く。

このよ 5 に，3 月下半期から 9 月上半期までの 6 カ月間には，降水の有無に関しては表日本と裹日本と の間には差が浔められない。盛夏，表日本に雷雨が多いようであるが，年の分布は局地的なものであつ て, 表日本・亳日本の差ということはできない。すなわち，この差はたざ冬半年にのみ現われると結論で きる。

各期の天候界を 1 年間を総括した図，第 7 図，第 8 図はをさに冬型を示して和り，夏半年のパターンは ほとんど無視できる。

第 8 図によつて判る。もつとも重要なことは,

1）もつとも確からしい，表日本と裏日本の気候区界の位置と，

2）そして，その境界の持っている意義は場所によって㟟つていて，もつとも大きい頻度 (中国山脤) が 12，すなわら，半月内に天候界ができることが半年あること，

3) 漸移带の幅がかなりあつて, 雁行する所もあるということである。

\section{V. 結 語}

気候区界に関するるこれでの結論は，日本の気候の大区分への資料になるが，これだけではまだ区分は

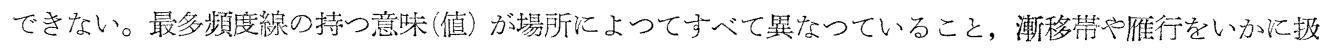
らかが問題である。これらは小区分が決らなければ解決しない。小区分決定の指標としては，他の気候要 矮を便う前に，今得られた頻度図上の低い稜線を使うとともに，それに表現され得なかつた東西差の境 


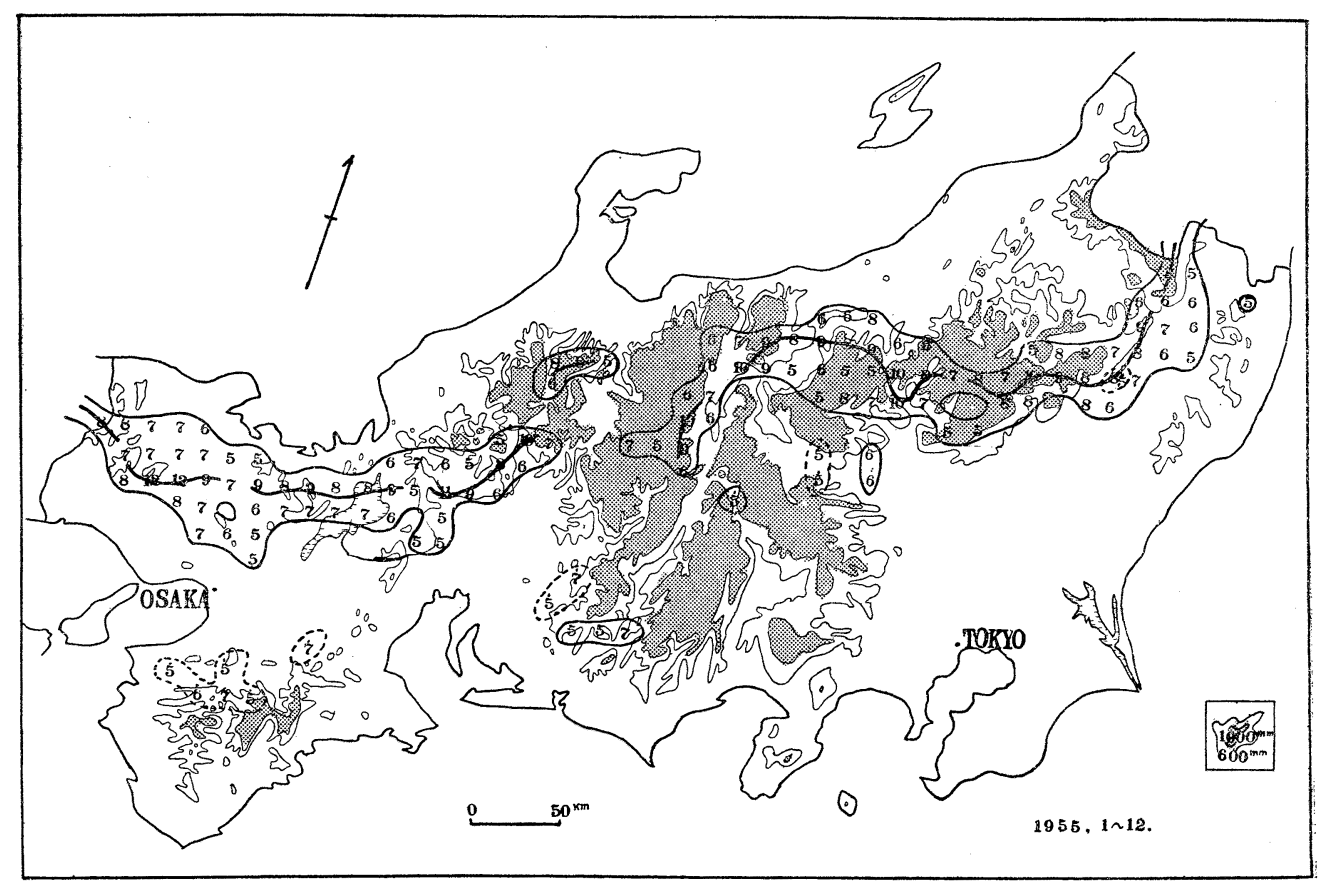

第 8 図 年問天候界頻度図 軸線（気候界）は 8 以上の部分だけを示した

界，およびこっでは全く説明を省略した多雨帯を使うことが良いと考劣る。それには基困になつた日雨量 分布図(第1図，第 2 図)が，最良の資料としてある。今回はその园中の $0.5 \mathrm{~mm}$ の線を使つたにすぎな い。

最後に, 御指導をいたざいた多田交男・矢沢大二両博士と, 東京大学地理学教室の方々飞感謝いたしま: 于。

\section{参考文献}

矢沢大二: 気候学, 地人書館, 1956

Flohn, H.: Witterung und Klima in Mitteleuropa, Zürich, 1954

Schirmer, H. : Die räumliche Struktur der Niederschlagsverteilung in Mittelfranken, Rema-gen, 1955

Knoch, K. u. A. Schulze: Methoden der Klimaklassifikation, Gotha, 1952 